\title{
In my skin: racial education and post abyssal thinking of black aesthetics
}

João Paulo Xaviera (1)

\begin{abstract}
This work, which is a fragment of a research that has been discussed in lectures and presented separately in other journals and books, examines through the lens of critical racial literacy, the discrimination, tension, and racism experienced by Afro-Brazilian persons due to the aesthetics of their phenotypic traits. The theoretical framework draws on Critical Race Theory (LADSON-BILLINGS, 1998; FERREIRA, 2014) and Epistemologies of the South (SANTOS, 2014) which provided the basis for data analysis. The methodology for data gathering was autobiographical narratives provided by the informants, who were selected due to their experiences of the subject. The primary research instrument was an online questionnaire, voluntarily and anonymously, answered by the participants. The results show that black people in Brazil face issues of race and racism in their own homes, at schools and universities as students, as well as in their working environments. The discussion is pertinent to the field of Applied Linguistics and Education as it highlights the paramount importance of developing a critical racial literacy at schools, which can address these issues and overcome racism from a variety of perspectives.
\end{abstract}

Keywords: Racism. Racialization. Education.

Critical Racial Literacy.

Recebido em: 01/03/2021 Aceito em: 30/05/2021

${ }^{a}$ Centro Federal de Educação Tecnológica de Minas Gerais (CEFET). Belo Horizonte, MG, Brasil.

E-mail: prof.joaopauloxavier@gmail.com

\section{How to cite:}

XAVIER, J.P. In my skin: racial education and post abyssal thinking of black aesthetics. Gragoatá, 
${ }^{1}$ I would like to thank Professors Joel Windle and Ricardo Almeida for the linguistic review.

${ }^{2}$ Technical education colleges provide secondary and further education and are run by the Brazilian Federal government. The present discussion is located at one such college, the Federal Center for Technological Education of Minas Gerais (CEFET-MG), a large, multi-campus institution.

\section{Introduction $^{1}$}

The initial motivation for this research was an experience I had as a professor at the Technical Education College ${ }^{2}$ where I work. In November 2019, two weeks before The Black Awareness Day, a group of students came to me and reported a disturbing situation that had occurred during one of their classes. According to the students, whilst checking the attendance list, the teacher, identified here as T, asked them for help to identify who were the absent students.
T: - Who are these two absent students?
Students: - They are so-and-so - [mentioning their nicknames]
T: - So-and-so sits here, right? (The teacher points to a table on the left side of the room.
Students: - Yes. He does.
T: What about So-and-so? Where does he sit? [referring to the other student]
Students: - He sits there, in that corner. He has not come to class because he is on medical leave. He'll be back tomorrow.
T: - Ah! I know who he is. Is he that boy with the "steel wool" hair? [comment followed by a laughter]

The students were visibly embarrassed by that racist comment about their classmate and the silence that befell for the next few minutes was broken after a black female student who felt deeply offended vented and said: "Yeah! That's heavy".

Upon hearing that report, I was utterly embarrassed. Firstly, because I am a black man whose hair is very curly and, therefore, the professor's comment also affects me. Secondly, I was embarrassed that such an occurrence would take place at a public educational institution. I explained to them the inappropriateness of that comment and how racist it was, and, therefore, a crime under Brazilian law. I reinforced that we, public servants, must commit to the ethics, the respect, the recognition, and appreciation for the diversity of cultures of which we are part. I also informed them of the existence of the Coordination of Gender, Race, Affirmative Actions and Identities (CGRAI), which is an advocate for gender and racial equality within the college. As they asked me how they should address that issue, I told them that reporting the fact to the campus directors would be the first step. 
On the following day, the offended student came to me after he was informed by his colleagues of what had happened. As we talked, I asked him how he was feeling about it and what would he like me to do. He admitted being hurt due to the professor's comment and that he would like to report that aggression, even though he feared retaliation. With his consent, I advised him to gather his colleagues who had witnessed the situation and invited them to the directors' office. There, we were welcomed by the campus directors who were officially informed about the situation. At the end, I requested that a minute of the meeting be drawn up and that all those present sign that document. The document was provided and signed by all of us, however neither the students nor myself received any copies of it at that time or later.

On Black Awareness Day, November 20 ${ }^{\text {th }}$ I hosted a collective breakfast with the students from the college. I spoke of the importance of denouncing and fighting all forms of racism. We discussed the importance of respecting cultural and racial diversity and stressed that, although our context of action is local and restricted to our families and internal communities, we need to stimulate the debates and the actions aimed at raising awareness about racism and how it profoundly affects the lives of black people.

Although this situation happened in November 2019, up to the moment of this publication we have not heard anything of the institution's position regarding the occurrence. Unfortunately, racist comments about the black skin tone, thick lips and curly hair often occur. The students' discomfort before the racist comment reveals how black people usually feel when having their aesthetics rejected and mocked through comments that ridicule their phenotypic traits or the style that they adopt in their daily lives.

In order to draw out the issues raised by this ethnographic vignette, I will discuss, in the light of Critical Race Theory (LADSON-BILLINGS, 1998) and Critical Racial Literacy (FERREIRA, 2014) the autobiographical narratives (CLANDININ; CONNELLY, 2000) of black people who face racism and how these subjects understand their hair, skin and artistic expressions. That is, how their aesthetics constitute an important part of their identity under conditions of structural racism. 
My main argument is in favor of an educational approach that encourages the practice of Critical Racial Literacy (FERREIRA, 2014). I view this approach as presenting strategies capable of contributing to discussion of ethnic-racial issues and antiracist struggle as part of an education that raises students' critical awareness of race and racism. Several authors have investigated this field and the results of their research point to the need to (re-)think an anti-racist education that embraces the diversity expressed through the multiple identities and aesthetics of social actors.

This paper is a fragment of a study conducted with the support of the Critical Study Group for Ethnic-Racial Relations (GECRE) linked to the Federal Center for Technological Education of Minas Gerais (CEFET-MG) and accredited by the National Council for Research and Development (CNPq). The questions asked aimed to elicit respondents' reflections about their personal stories and experiences with racism, including the social pressures they face from the rejection of and discrimination against their aesthetics and their phenotypic traits. In Brazil, these have historically been manifest through an aesthetics of whitening, that includes straightening and dying hair (for women), shaving hair (for men), strict adherence to formal or business-like dress codes (including uniforms), skin-lightening make-up, and, more recently, plastic surgery. By contrast, affirmation of Afro-diasporic identities has involved aesthetic valorization of natural hair, and dress and make-up that follows Afro-centric models, such as turbans, beads, and items associated with African-based religious practices. Considering this aesthetic marking of whiteness and blackness, the following questions guided the original research:

1. How do black men and women perceive the connections between racial identity and aesthetic identifiers of blackness (including hair styles and skin tone) in their daily lives?

2. What pressures do black men and women face to conform to aesthetic markers of whiteness?

3. What forms of racial discrimination do black men and women experience in relation to aesthetic markers of blackness? 
4. What possibilities exist for addressing aesthetic racism in schools?

From this perspective, extensive data collection was undertaken through the Autobiographical Narratives research methodology. Due to size restrictions, on this paper, I will address only some issues regarding the dark skin complexion and some of the difficulties black people face when confronted by what I call aesthetic racism. Other aspects that have emerged about black aesthetics, including black bodies and other aesthetics through which black people express themselves (art, architecture, music etc.) will be published in future papers. Considering the best way to present the research results, firstly Critical Race Theory and Critical Racial Literacy will be summarized. Then, I will make an overview about skin and its complexities. Finally, I will introduce the concept of aesthetic racism, which is explored more fully in my book "Racismo Estético - Decolonizando os corpos negros" (XAVIER, 2020).

\section{Critical Race Theory \& Critical Racial Literacy}

Critical Race Theory (CRT) was first studied and discussed from an educational and pedagogical perspective through the work of Ladson-Billings and Tate (1995). Ladson-Billings is a researcher and professor in the Department of Curriculum and Teaching at the University of Wisconsin. Her work in the field of curriculum development and multicultural education is internationally recognized for its high quality. According to Ladson-Billings, CRT tells us that there is another story to be told and it is strongly based on the recovery of histories and memories as opposed to the traditional, empirical, and sterile presentation of the facts. In CRT applied to education, other areas of knowledge, such as sociology, anthropology and a variety of other disciplines are used to analyze educational phenomena from a critical perspective (GANDIN, 2002).

For Ladson-Billings, the premises that justify this theoretical incorporation to the practices and to the epistemologies of education are the lack of theorizations about the construct and the implications of the concept of race. In this sense, issues and tensions related to social class and gender have, fortunately, received some attention and been discussed, 
however some more delicate concepts such as ethnicity should still be more deeply discussed.

There are five fundamental principles of CRT which were analyzed and summarized by the Brazilian researcher Aparecida de Jesus Ferreira, whose studies pointed to a broader understanding of the need to incorporate educational approaches that could lead students to a Critical Racial Literacy.

Based on the works of Milner and Howard (2013), Ferreira (2014) summarizes these principles as follows: the intercentricity of race and racism; the challenge to the dominant ideology; the commitment to social justice; the interdisciplinary perspective; the centrality of experiential knowledge. This last one, understood as the recognition of the empirical knowledge of non-white people as credible, highly valuable, and essential for understanding, analyzing, and teaching racial subordination in all its facets. Critical Race Theory explicitly seeks out, analyzes, and listens to the experiences of Black people through counternarrative - counter-storytelling methods, such as family stories, parables, testimonies, and chronicles (FERREIRA, 2014, p. 243). An understanding of ethnic-racial issues is essential in a society like Brazil, whose historical capitalist development was based on enslaved labor and that until 1889, just under 150 years ago, considered black and indigenous people to be the property of white people.

According to Ladson-Billings (1998), the transition and breaking of this nefarious paradigm from slavery to citizenship was not something simple nor welcomed without resistance by the dominant group; there tension was established. This tension remains. The difficulty in seeing Afro Brazilian and indigenous peoples as human beings who should be respected and receive equal treatment and as much representativeness as white citizens do, can be seen in the rejection of the phenotypic traits and cultural practices of such peoples, as well as in the erasure of the stories of black history and memory and, of course, in the lack of equal opportunities. The reference for the analysis of the narratives collected is theoretically based on the fifth principle presented by Milner and Howard (2013) and summarized by Ferreira (2014), that is, the "centrality of experiential knowledge".

CRT uses the contributions and epistemologies of other disciplines and fields of study to emphasize the importance 
of building an understanding that values the knowledge, history and representativeness of groups, previously enslaved and dominated, in environments that, historically, have been elitist, exclusionary and racialized in order to segregate black people. An example I could use is the Quechua People in Peru and Bolivia, who face ethnic and cultural discrimination by the white population descended from the Spanish people, who are a minority in these countries, but also, economically, the most wealthy and, therefore, the dominant group.

Thus, the notion of race cannot be simplified or left out of the debate; it must receive the attention that is due to it. If "social classes are real in the sense that we can fit people into the economic hierarchy; gender is real in the sense that we can at least talk a little bit about biology, about sexuality. But race is a moving target. What is white in this place is not white" (GANDIN, 2002, p. 280).

In this perspective, I argue that education should be ideologically guided to deconstruct cloudy understandings and prejudices that strive to lower the African diasporic people and our history and culture. This need dialogues directly with and, therefore, meets the Critical Pedagogy defended by Paulo Freire, who was an advocate for a pedagogical practice that realizes the importance of recognizing different cultures as a path that contributes, amongst other aspects, to the development of critical thinking regarding the contents, subjects and experiences to which students are exposed. Similarly, a critical educational approach raises awareness of the question of the validity and origin of information received, stimulating students' curiosity to ask questions and the share information. In doing so, students expand their perceptions of the social relationships of which they are part and to which they are subject as well as the social actors entangled in them. Ladson-Billings similarly advocates an autonomous education and cultural competence that enables children to understand who they are, where they come from and why these things are important to help them learn (GANDIN, 2002).

Understanding our place in the world and how our origins, cultures and interests come together to form our identities and subjectivities contributes to the educational process that shapes, informs, accepts, and includes, as opposed to the exclusion racism imposes. The parallel I outline 
between CRT and Paulo Freire's Pedagogy is due to the need of an awareness that extrapolates school limits, reaches the communities and encourages students to question the current system and the standards established in the social relations of power, of cultural and economic domination. Such an approach seeks to unveil the interests served by these unequal relations, who benefits from the ideologies embedded in them, and what their impacts are.

Currently, in Brazil, several researchers have dedicated their investigations to examine racial issues. In Applied Linguistics, Moita Lopes (2002) discusses identity constructions of black people; Souza (2011) focuses on black art and the literacies of re-existence; Pessoa and Urzêda-Freitas (2012) present some of the challenges posed by critical language teaching; Ferreira (2007, 2008, 2011, 2012, 2014) introduces experiences with racism and racial education. The latter significantly contributes to my understanding of critical racial education.

Like Ferreira, I question the fact that, despite the laws promulgated and the implementation of public policies that mandate the teaching of the cultures and the history of Afro Brazilians, it is still possible to experience both racism and social exclusion, from basic schools to higher education. I am a professor at a Federal institution, and I have had a class in which the only black student was not even Brazilian, but a foreign exchange student.

Racism is a structural characteristic of Brazilian society, according to Almeida (2018) and, therefore, cases of racism in school settings are common and are sometimes reported in Brazilian news. In 2019, for example, the media reported on a white student refused to take a sheet of paper containing written tasks from the hands of a substitute professor at the Federal University of Recôncavo da Bahia (UFRB) because she was a black person. Listening to such stories, reflecting about their impact, and taking actions that can result in social changes are imperative for the development of an anti-racist education. Stories like this find space in Critical Race Theory, for which social reality is built by formulating and exchanging personal stories and experiences. These narratives "serve as interpretive structures from which we impose order on 
experience and experience on us." (LADSON-BILLINGS \& TATE, 1995, p. 57).

Ladson-Billings and Tate understand the importance of these narratives of racialized subjects, because through them it is possible to understand their experiences and how society works and organizes around these social interactions and relationships (LADSON-BILLINGS, 1999, p. 219). This understanding inevitably makes it possible to reflect on how education can adequately contribute to form and transform individuals, raising their awareness of social relations and how their subjectivities are formed. Thus, Critical Racial Literacy becomes essential in this diverse and always conflicting field.

Guinier (2004) argues that Racial Literacy is a concept that seeks to understand the ontological experiences, interactions, economic, political, cultural, and educational relationships of individuals. In the urgency and tensions that arise from these encounters, race is highlighted by its potential as a vehicle for control in these social relations of power and domination, both geographically and economically.

Expanding these ideas, Ferreira (2014) advocates for a more just and egalitarian society based on the acceptance and mobilization of all identities, whether white or black, and invites reflection and action to fight racism as a societal urgency. This can be carried out with the promotion of criticality in the school context in a transdisciplinary approach because "the area of language is also responsible for educating citizens who are critical and reflective about how racism is structured in society" (FERREIRA, 2014, p. 250). Thus, I follow Ferreira in highlighting the need for the appropriation and application of a Critical Racial Literacy approach. This process encompasses a "set of pedagogical tools for the practice of racial literacy in the school environment with children, their peers, colleagues and so on" (FERREIRA, 2014, p. 251).

\section{Skin complexion and its complexities}

Skin is much more than the largest organ in the human body. Science proves that the skin is responsible for human circulation. It acts as a barrier against bacteria or viruses, it thermally regulates the body and all the sensorial functions, such as touch, pressure, cold, heat, pain, pleasure, are felt by it. 
When it comes to more than biology, the skin of black people is complex, strong and can be understood as books in which the passage of time is recorded. When I look at my grandmother's face skin, now 71 years old, I see the wrinkles that signal her mood, spots caused by the sun that witnessed her hard life in the fields, the scars as deep as the experiences that caused them.

The skin is the first perception we have when we see someone, so it is responsible for racial determination. The skin was the reason why racist theories, such as Social Darwinism, postulated by Herbert Spencer (GODOY, 1988), were disseminated. In this deeply ideological theory, it was proclaimed that inequality between people would be a natural phenomenon and, therefore, some would naturally be superior and others inferior. Life in society would be a constant struggle and only the strongest would reach success, be prosperous or capable of great deeds, likewise the same understanding would justify why only a few would have access to power and social prestige. Logically, on the other side of the coin, there would be the weak, inept and inferior, in the skin of blacks.

According to Spencer, whites were superior to blacks and the bio-sociological selection process of the elites suffered from the interference of the State, which acted to reduce inequalities. For Spencer, the poor and the unfit should be made extinct. At the same time, several fields of studies used Social Darwinism to study social relations (JACQUARD, 1984, p. 25). Anthropology and Ethnology, from the phenotypic characteristics, understood that the construct "race" appears as a phenomenon resulting from these differences. Genetics started to discuss a way to categorize people. For this, they analyzed the phenotypic traits: skin color, hair texture, bone structure and skull shape. Psychology and Neurology investigated the academic performances of different social groups, as a way of determining the superiority or inferiority of the subjects (JACQUARD, 1984, p. 27). This last example brings to my memory the attempts used today to justify the academic success of white students when compared to that of black people, some call it meritocracy. I draw this parallel and ask this question: how can the different social contexts in which individuals are inserted be ignored when analyzing the successes or failures of these people? In other words, how can two students with different access to information, training, 
food and means to keep a student life pursue an academic journey and compete on an equal footing, when what is required from them does not considered the journey taken by these subjects?

The light is white and the darkness is black. Angels are white and full of light whilst the demons are black and full of darkness. Cleanliness is associated to light and the dirty to darkness and obscurity. The conflicts between the shades of light and color can be used to illustrate these racial tensions that we are reflecting on. Some metaphors, when attributed to people, express racism, because they are used to define well-being or, perhaps, a subject that is considered good as "clear", "clean", "white". What, then, would be left to the things and people that are not included in this hue? It is necessary to recognize that there are mechanisms in the visual arts, in the cinema, in photography, in the world of entertainment that discriminate against our identities. More about this can be read in my book, already mentioned. When we observe films and series in which black actors are not selected for the roles of protagonists, we can understand this (not always) subtle rejection of black aesthetics. We should think about the effects of this choices for black people who do not see themselves represented in the media or in entertainment industry products. If the heartthrobs or the beautiful characters in a soap opera, movie or tv series always have different aesthetic characteristics from mine and those characteristics are the ones considered beautiful and attractive, therefore I must understand that my negroid aesthetics are not welcome, represented nor remembered because I am neither beautiful nor desirable. When the ideal of beauty lies in straight hair flowing in the wind, white skin and blue or green eyes, we can spot the aesthetic racism right before our eyes.

One of the survey respondents reported that she had a very difficult experience. In her childhood, she heard her curly hair was ugly and, because of this, she always used hair straighteners. Her mother urged that she never left home without having her hair tied or straightened. So, this girl used even the hot iron comb to keep her hair under control and also applied chemicals to interfere with the natural structure of her hair strands. In order to feel beautiful, she needed to have her hair straightened. At 19, a severe baldness spread throughout 
her scalp and, because of this, the girl suffered a major trauma: having to shave her head. The treatments to reverse it were not as successful as she wanted, however it was possible to let her hair grow again. Today, she wears box braids and feels more confident with her hair as, now, she accepts herself. The braids restored the girl's self-esteem.

The heart of the discussion I propose is to show that black people are worthy of respectability like any other human being and must be remembered and treated as such, as well as considered and invited to represent a wide diversity that constitutes Brazilian blackness. Many stereotypes built about the black people are legacies of slavery and theories such as Social Darwinism which brings alongside the imposition of whiteness aesthetics on black people. No wonder this destroys our self-esteem as blacks and deprives us from the pleasure of living under our own skin. This mentality stimulates the unsuccessful attempt to try to fit in this beauty standard imposed by whiteness and, even, the desire to change skin pigmentation.

A report released by the Global Analyst Report, in August 2020, during the crisis caused by Covid-19, estimated that the cosmetics industry used to lighten the skin remained unshaken and worth about US\$ 8.6 billion with positive growth and profit projections that could reach more than US\$ 12.3 billion dollars, by 2027. According to the data available on the website of the World Health Organization (WHO), among the products used to bleach the skin are: soaps, creams, exfoliants, pills and even injections with substances developed to decrease the production of melanin. There are products that promise to speed up epidermal depigmentation. They contain harmful substances, such as mercury. WHO warns that mercury can cause several health problems: damage to the kidneys, spots or discoloration of the skin, attacks on the immune system that decrease resistance to infections by bacteria or fungi, anxiety, depression or psychosis (UNEP, 2019). According to WHO (2017), in general, 4 out of 10 women in Africa use products that promise to bleach their skin tone. Nigeria has the most alarming numbers, approximately 8 out of 10 women are customers of this type of product.

In 2018, Ghanaian authorities warned pregnant women not to take bleaching pills that contained the antioxidant 
glutathione. Women were taking the pills hoping that they could bleach the babies' skin, still in gestation.

In Togo, 59\% of women use these bleachers; in South Africa, 35\%; in Senegal, 27\% and in Mali, 25\%. These frightening numbers are spread across Asia where 6 out of 10 Indian women use these products; in China, 4 out of 10 . Other countries were cited, the Philippines, Thailand, Sri Lanka, Indonesia, but the data for Brazil were not included (WHO, 2017).

These consumers are victims of this aesthetic racism and, the most absurd fact behind these numbers is the social condition of the people who consume them. Poverty and social inequality in these countries are dramatic issues and represent a major challenge for any government, yet the desire to fit in a standard of beauty goes beyond vanity. In these countries, the people who have better living conditions or who enjoy privileges are majorly white people. Thus, the racial issue deepens class differences and becomes a decisive factor when making a choice: a bleaching cream for me to improve my life or my next meal?

Numbers like these denounce the aesthetic imposition over black people and reveal how it can influence a person's self-esteem and lead them to put their own lives - and even the lives of their unborn children - at risk, in order to achieve an idealized beauty standard.

As I discussed before, aesthetic appreciation and beauty are subjective observations of the social subject. In 2017, I had the opportunity to travel to Thailand. I visited the capital, the north and the beaches in the south of the country. I am a Brazilian man who is used to seeing bathing suits and, practically, nothing embarrasses me in relation to the human body. When I removed my T-shirt and shorts, I noticed that the people around me looked at each other and whispered something that made them giggle. At first, I did not care, but I became very curious when two girls approached and asked to take a selfie with me. At that moment, I thought they were mistaking me for someone famous. - "But with whom?" I thought. If there was a famous person with this face of mine, I would certainly know! After posing for the selfie with the girls, I asked the tour guide who was with me why was I asked for a picture. He told me that the city where we were was not a tourist destination, "specially by people like me", he said. 
My curiosity grew bigger, and I continued to listen to what he was saying. Visibly embarrassed, the guide told me that I am very handsome for the Thai standards and that in that part of the world my skin tone is unusual and very admired. I was flattered, but at the same time deeply reflective for considering myself a common type of black Brazilian man. Everyone in my family has this Brazilian face, curly hair and a brown skin inherited from my great-great-grandmother who was an indigenous woman. So, it never occurred to me that I could get any attention for just being who I am and how I am, but in that context among those people my phenotypic traits were read differently than I was used to.

The same thing happened to me when I met a South Korean friend in London. It was the first time I spoke to someone from South Korea and his first time talking to a black and Brazilian person. After two hours of conversation, he asked me if he could touch my hair. I authorized it, even though I do not usually do so. His laughter preceded the phrase: “Can you change hair with me?" The same curly hair that in my country is called steel wool hair, for someone from another culture is seen as something stylish and beautiful.

In 2018, I worked for three months at a private school in Minas Gerais based in the high mountains of the city of Nova Lima. The privileged view, the typical cold weather from the mountain range and the institution's facilities were a new side of a type of Brazil that I did not know up to that point. I have always worked at public schools and back then I had been a municipal English teacher for 4 years. The structures offered to the teachers and the students at that private school were more advanced than the ones I had even at university. Notebooks and tablets for students and teachers, cinema room, amphitheater, specific libraries for each educational segment: elementary (I and II) and High School. I was hired as head teacher and was supposed to teach art, science, geography, and history for fifth graders. On my first day, I usually propose some games and dynamics to get to know my students and establish a connection with them. The answers to my questions were unprecedented, for me. When I asked them to think of an unforgettable place and describe it to the class, so we could try to guess, nothing in my four years working at the public school system had prepared me to guess the unforgettable places 
those kids had already experienced: Vienna, Italy, France, "My father's farm in Uruguay". The world, in the words of those students, looked like a bingo card in which each country visited would be crossed. Despite all these trips and privileges, an experience was new for them: having a black teacher.

They tested my linguistic knowledge about "difficult" words in English, asked me where I had studied, which university I had graduated at, if I had already visited the United States (when I answered this question with a 'no') they immediately lost interest in me, which was regained after I informed them that I had lived in England for two years. They asked other questions about my family, where I was living at that moment; they wanted to know if I spoke other languages and, finally, when I thought I was about to be approved at that cross-examination, they asked me to touch my curly hair.

In that classroom, there was no other black person besides me. Another perception that intrigued me was the height of my students. Most of them were over $5^{\prime} \cdot 3^{\prime \prime}$. At the city hall schools, my students were less than $5^{\prime} .2^{\prime \prime}$ and were the same age group as them.

I bring this information to discuss another experience reported by a Beninese friend with whom I studied some subjects during my doctorate. Once, while we were talking about his country and the racial issues there, he told me that if I visit his country, I should be aware that on the street people would notice my skin and some beggars could even ask me for money. I asked why that could happen and was told that the upper social classes in Benin are mixed with European blood and often have less black ethnic traits, thinner lips and the skin tone may be less dark, which is my case. Generally, these people are taller than the others because they can eat better; this explains the difference in stature that I noticed between public school students on the outskirts of Belo Horizonte and the students from the private school where I taught. Food.

On Netflix, there is a documentary called Skin. It shows how the cosmetics industry benefits from people's social vulnerability to profit from creams and other products that promise to bleach their skin. I mentioned my conversation with my Beninese friend because in the documentary, a 9-year-old black child says he would like to have a lighter skin. He said 
that he would not like to be white, but that he would like to have a lighter skin because "Black is bad. Black-black is really bad".

When the journalist asked why the boy wanted to lighten his skin, he replied that he did not know why, but that a lighter shade is better. The boy's response underpins everything we have discussed about how aesthetic racism affects our lives, even when we are not completely aware of its presence.

The need to feel accepted, represented and loved is inherent to humans. When we cannot be what we are because we will be considered inferior, ugly, or nonstandard, our tendency is to try to fit into a model that people like and accept.

In 2019, the American singer Beyoncé Knowles released the song Brown Skin Girl. According to Billboard, which is a weekly magazine founded in 1894 and specialized in information about the music industry, this song ranked 68th among the best songs of that year because it reinforces Beyoncés crusade for cultural pride and female empowerment. Teen Vogue magazine described the song as a celebration of blackskinned women. The Guardian newspaper called the song brilliant. On the internet, it is possible to watch several black women singing and reacting to a song that accepts and extols their beauty. Most of these videos are exciting and emotional. Likewise, the official video clip that has been watched more than 21 million times on the singer's youtube channel. Black beauty exists and we black people are aware of it and we are still waiting for more songs about us, advertising campaigns that do not make us invisible, protagonists who represent us and brands that see and respect us as consumers.

The movement calls for greater contemplation of physical types not considered "standard" by advertising: such as fat, short bodies, elderly people, trans people, etc. Everything that is not part of a Caucasian-thin standard has been constantly demanded to be part of the campaigns. The absence of such physical types - in favor of the white body, mainly - is one of the forms of invisibility, a type of "work of silence" faced by black Brazilian citizens. (MIRANDA, 2018, p. 5)

I consider it a shame that toothpastes, for example, display advertisements where only white people appear taking care of oral hygiene. I do not remember watching a single advertisement with black people. Brands ignore the consuming 
power of black people. Similarly, the brands of aesthetic products for black skins. Countless times have I heard black women in my family complain about makeup products. I heard them say that even the darker ones were never appropriate for their skins and made their faces gray. In the country with the highest concentration of black people outside Africa, we still have difficulty finding products suitable for black skin.

The black women want to consume high quality products made specifically for their skin and hair. How difficult is it to find a dermatologist who has specific products for black skin. It is not easy for us, blacks, to find professionals who have specific products for black skin and who perform a common procedure such as a peeling, which is an exfoliation for skin renewal.

Recently, I have been paying even more attention to advertising campaigns and product images that companies want me to consume. At the supermarket, when picking up a shampoo, I noticed that the label said: 'combing cream for curly hair types $4 a, 4 b$ and $4 c$ ', but the image on the label showed a white person with open curls hair! My hair has closed curls and I am a black person. There is a lack of respect and zeal towards black consumers and a clear lack of interest in our aesthetics.

The same happens regarding sunscreen campaigns, which are another situation in which stereotypes are perpetuated each summer. I cannot recall watching a tv commercial or seeing an advertisement in magazines bringing recommendations for black people wear sunscreen. Only white people figure in these advertising campaigns. This contributes to perpetuating the myth that black people do not need to protect themselves from the sun. Everyone needs to protect themselves from ultraviolet rays because skin cancer is the most common tumor in Brazil, accounting for 33\% of all cancer diagnoses in the world. Annually, 180 thousand new cases are identified, according to the data from the National Cancer Institute. Another example is a brand that offers a product capable of healing scars. It is sold as an accidental discovery of medicine and that the product can restore the damaged skin. O.K. The poster girl is a renowned Brazilian journalist, a white person, who is over 70 years old and has wonderful skin. O.K.! But I am a black man and I am aware that not all skin products have the same effect on my skin, will it work for me too? These 
are simple examples, but they demonstrate how the aesthetics of the whiteness are imposed over all others and dominate the media, the arts, the entertainment and, consequently, in advertising campaigns.

Anti-racist education and the practice of Critical Racial Literacy are part of a project to deconstruct and overcome racism. The facets are multiple and involve the recognition of differences, respect for plural black aesthetics and the end of the rejection of black beauty and the imposition of a Caucasian or European aesthetics over others. The theme is broad and permeates issues that directly impact the construction of black people's self-esteem and how these subjects come to see and recognize themselves in their own bodies. In this perspective, I see the school, therefore, as a boarding gate or custom between the borders of knowledge and racism. The teachers are their customs agents who need to have a broader view on the social relations established in society and access to more contents and materials that can be pedagogically used to expand students' knowledge about these racial tensions. I consider that the social pressures and deprivation of the freedom of black people to express their subjectivities through their own bodies is a serious aggression that needs to be reported to society and combated through a process of perennial racial education.

These reflections are part of the issues that are central to the discussions addressed by Santos (2014) regarding coloniality and post-colonialism which are seen through the lenses of critical analysis that revolve within the realm of the dominant productions and diffusion of knowledge and epistemology. When we reflect on post-abyssal thinking, we break the colonial paradigm of knowledge production and appropriation which still lingers in our societal relations and that reveal social aspects of the modern colonial experience and the divisions that fragmented the world into its metropolises and colonies; persons understood as civilized and uncivilized; beautiful and ugly; viewed and excluded. In establishing and imposing standards for the ways in which curly hair should be worn or how light should someone's skin be, society rejects the natural phenotypic traits of black people. I perceive this attitude as Aesthetic Racism and I understand that this concept is necessary to differentiate an important aspect of the identity 
constructions of black people: their body and the expressions of their subjectivity, such as art and other cultural expressions.

In this arena, each strand of curly hair receives a cultural and ideological charge from its root to its ends, as an element capable of strengthening the identity constructions of black people. Curly hair faces pejorative and racist evaluations and the denial of its beauty and the oppression and pressure to be presented under other aesthetics, often Eurocentric, that rejects the natural African hairstyles, accessories or any stylizations that resume the cultural heritage of the black people or that are simply different from what is expected or admired by/in white individuals.

According to Nogueira (1998, p. 199), "the notion of desirability of the Caucasoid traits, and, consequently, the undesirability of the negroid traits, is closely linked to the whitening ideology, which indicates miscegenation as recommended", dissolving the characteristics and identity constructions of the black people, seen as inferior since colonization. Similarly, the author questions: "the negroidal traits inspire the same attitude and the same feeling of aversion that tend to produce 'defects' or physical deformities". The deconstruction of this mentality needs to be fostered by an ideologically oriented education, which values and includes differences and contributes to the resignification of the gaze that rejects, disrespects, and tries to depose people from their own identities or remove them from their own bodies. I evaluate these attitudes as a systemic and chronic part of a racist project that we have denounced every day. I name this segment: Aesthetic Racism.

\section{REFERENCES}

ALMEIDA, Silvio Luiz de. O que é racismo estrutural? Belo Horizonte: Letramento, 2018.

CLANDININ, Jean; CONNELLY, Michael. Narrative inquiry: experience and story in qualitative research. San Francisco: Jossey-Bass. 2000.

FERREIRA, Aparecida. What has race/ethnicity got to do with EFL teaching? Linguagem \& Ensino, v. 10, n. 1, p. 211-233, 2007. 
FERREIRA, Aparecida. Limites, desafios e possibilidades para aplicação de estratégias anti-racistas e da Lei Federal $n^{\circ}$ 10.639/2003. In: Ferreira, A. J. (Org.). PEAB - Projeto de estudos afro-brasileiros: contexto, pesquisas e relatos de experiências. Cascavel, PR: Unioeste, 2008. p. 47-60.

FERREIRA, Aparecida. Addressing race/ethnicity in Brazilian schools: a critical race theory perspective. Seattle - USA: CreateSpace, 2011.

FERREIRA, Aparecida. Histórias de professores de línguas e experiências com racismo: uma reflexão para a formação de professores. Revista Espéculo, v. 43, nov. 2009 - fev. 2010. Disponível em: <http://www.ucm.es/info/especulo/ numero42/racismo.html>. Acesso em: 9 fev. 2011.

FERREIRA, Aparecida. (Org.). Identidades sociais de raça, etnia, gênero e sexualidade: práticas pedagógicas em sala de aula de línguas e formação de professores/as. Campinas, SP: Pontes, 2012.

FERREIRA, Aparecida.(Org.). Relações étnico-raciais, de gênero e sexualidade: perspectivas contemporâneas. Ponta Grossa, PR: EdUPEPG, 2014.

GANDIN, Luis Armando; DINIZ-PEREIRA, Julio; Para além de uma educação multicultural: teoria racial crítica, pedagogia culturalmente relevante e formação docente (entrevista com a professora Gloria Ladson-Billings). Educ. Soc., Campinas, v. 23, n. 79, p. 275-293, Aug. 2002.

GODOY, Norton. Darwin: a evolução de um homem. Superinteressante, São Paulo, n.5, p. 41-51, 1988.

GUINIER, Lani. From racial liberalism to racial literacy: Brown $\mathrm{v}$. Board of Education and the interest-divergence dilemma. The Journal of American History, v. 91, n. 1, p. 92-118, 2004.

JACQUARD, Albert. Os mitos no microscópio. O correio da Unesco, Rio de Janeiro, n.1, p. 25-27, jan. 1984.

LADSON-BILLINGS, Gloria; TATE, William. Towards a critical race theory of education. Teachers College Record, v. 97, n. 1, p. 47-67, 1995. 
LADSON-BILLINGS, Gloria. Just what is critical race theory and what's it doing in a nice field like education? Qualitative Studies in Education, v. 11, n. 1, p. 7-24, 1998.

LADSON-BILLINGS, Gloria. Preparing teachers for diverse student populations: a critical race theory perspective. Review of Research in Education, v. 24, p. 211-47, 1999.

MILNER, Richard.; HOWARD, Tyrone. Counter-narrative as method: race, policy and research for teacher education. Race Ethnicity and Education, 16:4, p. 536-56, 2013.

MILNER, Richard.; HOWARD, Tyrone. Analyzing poverty, learning, and teaching through a critical race theory lens. Review of Research in Education, v. 37, n. 1, p. 1-53, 2013.

MIRANDA, Gisele Leitão. Representatividade e construção de identidade da mulher negra em folhetos da Avon. 2018. 58 f. Monografia (Especialização em Cultura do Consumo) Coordenação Central de Extensão, Pontifícia Universidade Católica do Rio de Janeiro.

MOITA LOPES, Luis. Paulo. Identidades fragmentadas: a construção de raça, gênero e sexualidade na sala de aula. Campinas, SP: Mercado de Letras, 2002.

NOGUEIRA, Oracy. Preconceito de Marca. As Relações Raciais em Itapetininga. São Paulo: Edusp. 1998.

PESSOA, Rosane. Rocha.; URZÊDA-FREITAS, Marci. Túlio. Challenges in critical language teaching. TESOL Quarterly, v. 46, n. 4, p. 753-776, 2012.

SANTOS, Boaventura de Sousa. Epistemologies of the South: Justice Against Epistemicide. Boulder: Paradigm Publishers, 2014.

SOUZA, Ana. Lucia. Letramentos de reexistência: poesia, grafite, música, dança: hip-hop. Campinas, SP: Parábola. 2011.

XAVIER, João Paulo. Racismo Estético: Decolonizando os corpos negros. Belo Horizonte, MG: Amazon, 2020. 


\section{Resumo}

\section{Na minha pele: educação racial e o pensamento pós-abissal da estética negra}

Este trabalho é um dos fragmentos de uma pesquisa já apresentada por meio de palestras e publicadas em outros periódicos. Nele são examinados através das lentes do Letramento Racial Crítico, a discriminação, a tensão e o racismo vividos pelos afro-brasileiros devido à estética de seus traços fenotípicos. Os referenciais teóricos baseiam-se na Teoria Racial Crítica (LADSON-BILLINGS, 1998; FERREIRA, 2014) e nas Epistemologias do Sul (SANTOS, 2014) por meio dos quais as análises dos dados foram feitas. A coleta de dados foi realizada por meio de narrativas autobiográficas fornecidas pelos informantes, selecionados em função de suas vivências e conteúdo de seus relatos. O principal instrumento metodológico foi um questionário online respondido de forma voluntária e anônima. Os resultados desvelaram que muitos negros no Brasil enfrentam discriminações raciais em suas próprias casas, nas escolas e universidades como estudantes, bem como nos ambientes de trabalho. A discussão é pertinente ao campo da Linguística Aplicada e da Educação Racial, pois destaca a importância do desenvolvimento dessa consciência crítica com vistas a abordar essas questões e combater o racismo a partir de uma variedade de perspectivas.

Palavras-chave: Racismo. Racialização. Educação. Educação Racial Crítica. 
João Paulo Xavier is currently a professor of the Language Department of Centro Federal de Educação Tecnológica de Minas Gerais (CEFET-MG). He earned his Ph.D in Language Studies from CEFET-MG. Graduated from Universidade Federal de Minas Gerais (UFMG) with a Master's degree in Applied Linguistics. He holds a B.A in English \& Portuguese (UFMG) and a B.A in Sociology earned at Centro Universitário Internacional (Uninter). He coordinates the Critical Studies Group for Ethinic relations (GECRE) accredited by CNPq. His research agenda includes exploring Critical Education, multiliteracy with an Emphasis in Educational Equity, Opportunity and Cultural Diversity. Author of: Racismo Estético: Decolonizando os corpos negros - available at Amazon.

[Doutor em Estudos de Linguagens/ CEFET-MG e Mestre em Linguística Aplicada ao Ensino de Línguas Estrangeiras/UFMG. É professor efetivo no departamento de formação geral do Centro Federal de Educação Tecnológica - CEFET-MG e líder do Grupo de Estudos Críticos para as Relações Etnico-raciais/ GECRE/CNPq.Seus interesses de pesquisa incluem Educação Crítica, Pedagogia dos Multiletramentos, Igualdade Educacional e Diversidade Cultural. Autor do livro Racismo Estético: Decolonizando os corpos negros, disponível na Amazon]. 